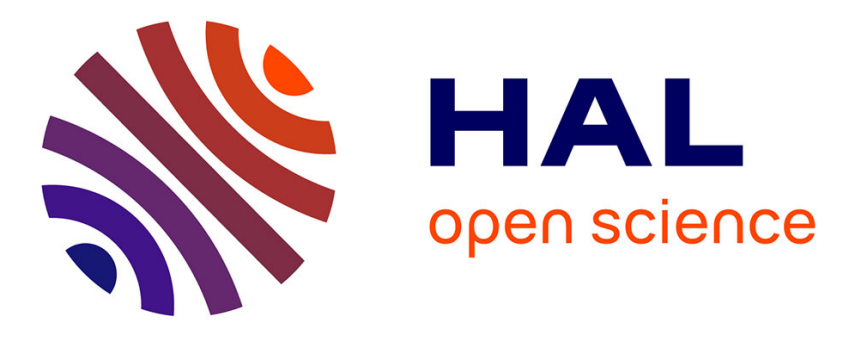

\title{
SOX11-related syndrome: report on a new case and review
}

Victor Wakim, Pratibha Nair, Valérie Delague, Sami Bizzari, Mahmoud Taleb Al-Ali, Christel Castro, Alicia Gambarini, Stephany El-Hayek, André

Megarbane

\section{To cite this version:}

Victor Wakim, Pratibha Nair, Valérie Delague, Sami Bizzari, Mahmoud Taleb Al-Ali, et al.. SOX11related syndrome: report on a new case and review. Clinical Dysmorphology, 2021, 30 (1), pp.44-49. 10.1097/MCD.0000000000000348 . hal-03147650

\section{HAL Id: hal-03147650 \\ https://hal-amu.archives-ouvertes.fr/hal-03147650}

Submitted on 16 Jul 2021

HAL is a multi-disciplinary open access archive for the deposit and dissemination of scientific research documents, whether they are published or not. The documents may come from teaching and research institutions in France or abroad, or from public or private research centers.
L'archive ouverte pluridisciplinaire HAL, est destinée au dépôt et à la diffusion de documents scientifiques de niveau recherche, publiés ou non, émanant des établissements d'enseignement et de recherche français ou étrangers, des laboratoires publics ou privés.

\section{(ㄷ)(1) $\$$}

Distributed under a Creative Commons Attribution - NonCommercial| 4.0 International 


\section{SOX11-related syndrome. Report on a new case and review}

Victor Wakim ${ }^{1}$,Pratibha Nair ${ }^{2}$, Valérie Delague ${ }^{3}$, Sami Bizzari ${ }^{2}$, Mahmoud Taleb Al-Ali ${ }^{2}$, Christel Castro, Alicia Gambarini ${ }^{4}$, Stephany El-Hayek ${ }^{2}$, André Megarbane ${ }^{4,5}$

${ }^{1}$ School of Medicine, Lebanese American University, Beirut, Lebanon.

${ }^{2}$ Centre for Arab Genomic Studies, Dubai, United Arab Emirates

${ }^{3}$ Aix Marseille Univ, Inserm, MMG U 1251, Marseille, France.

${ }^{4}$ Institut Jérôme Lejeune, Paris, France.

${ }^{5}$ School of Medicine, Lebanese American University, Beirut, Lebanon.

Correspondence: Andre Megarbane, Institut Jerome Lejeune, 37 rue des Volontaires; 75015 Paris, France. E-mail: andre.megarbane@yahoo.fr 


\begin{abstract}
:
The SOX11 gene is a member of the SOX (SRY-related HMG-box) family of transcription factors involved in the regulation of embryonic development and in the determination of cell fate. Recently, SOX11 variants were linked to cases of overlapping syndromes collectively termed SSRIDDs, which are mainly associated with variants in BAF complex genes. Patients with these various syndromes exhibit a spectrum of features including developmental delay, intellectual disability, feeding difficulties, hypotonia, short stature, microcephaly, fifth finger hypoplasia, behavioural problems and seizures. We report a novel de novo mutation in SOX11, c. 146T>A [p.Ile49Asn], found by exome sequencing in a middle eastern child with intellectual deficiency, developmental delay, microcephaly, thick scalp hairs, long eyelashes and eyebrows, and low-set ears. No abnormalities of fingers were noted. The SOX11-related SSRIDD and a review of SOX11 reported cases are discussed.
\end{abstract}

Key-words: Dysmorphology; SOX11; Variant; Exome 


\section{Introduction}

The differentiation of embryonic stem cells to neuronal progenitor cells (NPCs) and the subsequent generation of mature neurons and glial cells from these NPCs is a complex process directed by the sequential activation of gene expression by the SOX [sex-determining region Y (SRY)-related high-mobility-group (HMG) box] family of transcription factors. SOX11, a member

of this family, is required for the differentiation of mature neurons (Bergsland et al., 2011; Kavyanifar et al., 2018) and plays a critical role in axonal projection, radial migration and dendritogenesis (Shim et al., 2012).

This transcriptional regulator, encoded by a 9002-nucleotide-long, intronless gene, is highly expressed in the human fetus, in the gastrointestinal tract, lung, spleen, pancreas, kidneys, and gonads, but particularly in the nervous system (Sock et al., 2004; Potzner et al., 2010; Wang et al., 2013), illustrating its key role in embryonic development. Moreover, it has also been shown to be essential for adult neurogenesis (Jankowski et al., 2006; Salerno et al., 2012; Ninkovic et al., 2013; Mu et al., 2012; Wang et al., 2013).

Recently, defects in the SOX11 gene were reported in 7 patients, whose conditions fall into the class of the SWI/SNF-related intellectual disability disorders (SSRIDDs), a collective term suggested by Bögershausen and Wollnik (2018) to describe disorders related to BAF complex (also known as the mammalian SWI/SNF complex) genes. This term encompasses Coffin-Siris Syndrome (CSS; OMIM 135900), Nicolaides-Baraitser syndrome (OMIM 601358) and other overlapping syndromes. Collectively, these disorders exhibit a spectrum of features that includes developmental delay (DD), mild intellectual disability (ID), dysmorphic facial features, feeding 
difficulties, hypotonia, microcephaly, fifth digit nail/finger hypoplasia, prominent interphalangeal joints, brachydactyly, sparse hair, short stature, behavioural problems and seizures.

Here we report on a male Lebanese child with DD, ID and dysmorphic features, presenting a novel de novo mutation in SOX11. The SOX11-related SSRIDD and a review of SOX11 reported cases are discussed.

\section{Materials and Methods}

\section{Case Study}

The male patient was referred for genetic counseling and genetic workup because of developmental delay. His parents were not related, and the child was born after two miscarriages. An extensive clinical and paraclinical workup was done on the patient including EEG, EKG, brain MRI and Whole Exome Sequencing (WES).

\section{Molecular Analysis}

Informed consent for genetic analysis was obtained from the family in compliance with national ethics regulations. Genomic DNA was isolated from peripheral blood samples collected from the patient and his parents using standard techniques.

WES was performed on the patient. The analysis covered $99 \%$ of the exome with an average of 30 reads for the whole exome.

The parents were tested by Sanger sequencing for the analysis of a specific somatic mutation present in their affected son. The mutation was also confirmed in the patient by Sanger sequencing. 


\section{Whole Exome Sequencing}

Approximately $37 \mathrm{Mb}(214,405$ exons) of the Consensus Coding Sequences (CCS) were enriched from fragmented genomic DNA by $>340,000$ probes designed against the human genome (Nextera Rapid Capture Exome, Illumina) and the generated library sequenced on an Illumina NextSeq or HiSeq 4000 platform (Illumina) to an average coverage depth 70-100X. An end to end inhouse bioinformatics pipelines including base calling, primary filtering of low quality reads and probable artefacts, and annotation of variants was applied. All disease causing variants reported in HGMD®, in ClinVar or in CentoMD® (class 1) as well as all variants with minor allele frequency (MAF) of less than 1\% in ExAc database were considered. Evaluation was focused on exons and intron boundaries $+/-20$. All relevant inheritance patterns were considered, provided family history and clinical information were used to evaluate eventually identified variants.

\section{Bioinformatic Analysis}

In order to predict the effect of the identified sequence variations, different bioinformatics tools were applied; such as MutationTaster (http://www.mutationtaster.org/) (Schwarz et al., 2010), SIFT (http://sift.bii.a-star.edu.sg/) (Kumar et al., 2009), PROVEAN (http://provean.jcvi.org/index.php/) (Choi et al., 2012), PolyPhen-2 (http://genetics.bwh.harvard.edu/pph2/) (Adzhubei et al., 2010), and CADD (https://cadd.gs.washington.edu/) (Rentzsch et al., 2019). Homologene was used to study the conservation of the protein (https://www.ncbi.nlm.nih.gov/homologene) (Sayers et al., 2011). Lollipops was used to visualize the localization of the different variants along SOX11 (https://joiningdata.com/lollipops/index.html) (Jay and Brouwer, 2016). 


\section{Results}

\section{Case Report}

The patient, a boy, is the first-born child of healthy non-consanguineous Lebanese parents. He was born at full-term following an uneventful pregnancy and normal delivery, weighing 3250 $\mathrm{g}\left(42^{\text {nd }}\right.$ percentile). Although the patient's length and occipito-frontal circumference (OFC) at birth were not available, they were considered normal by the parents. At the age of 6 months, parents noted a delay in developmental milestones. At the age of 15 months, he had a $7^{\text {th }}$ cranial nerve paralysis, of unknown origin, that did not heal completely.

At the first examination, when he was two years old, he was unable to walk unhelped and could only say a few words. His length was $71 \mathrm{~cm}\left(15^{\text {th }}\right.$ percentile $)$, OFC 48 ( $35^{\text {th }}$ percentile $)$ and weight $11.8 \mathrm{Kg}\left(40^{\text {th }}\right.$ percentile). He had long eyelashes, a synophrys, thick eyebrows, low set ears, short but normal $5^{\text {th }}$ digit phalanges in hands and feet, a $2^{\text {nd }}$ toe longer than the hallux on the left side, and hypospadias (Figure 1). Laboratory investigations, including genetic tests, were refused by the family.

He was seen again at the age of 5 years. The major complaint of the parents was his severe developmental delay and recurrent buccal mycoses. He was able to walk unhelped since the age of 3 and his speech was still rudimentary. His height was $104 \mathrm{~cm}\left(10^{\text {th }}\right.$ percentile), and his OFC $49 \mathrm{~cm}\left(12^{\text {th }}\right.$ percentile $)$. Clinically, he had the same features seen before. Small $2-4$ toenails were noted, similar to his father. The brain MRI of the patient as well as the EEG, and EKG were normal.

\section{Molecular Results}

WES analysis showed a novel missense variant in SOX11, c.146T>A [p.Ile49Asn]. This likely pathogenic variant was confirmed in the patient by Sanger sequencing (Figure 2) and not 
found in either parent. The detected variant was neither found in gnomAD nor 1000G and was predicted to be deleterious by SIFT (score=0), probably damaging by PolyPhen2 (score=0.998), disease causing by MutationTaster (score=194), deleterious by PROVEAN (score=-6.469) and deleterious by CADD (score=34). The affected residue was shown to be conserved across several species (Figure 3).

\section{Discussion}

SOX11 is an essential regulator of embryogenesis and cell fate determination. It regulates the expression of multiple target genes, involved in various cellular processes (Wegner 2010; Sha et al., 2012). Its expression has been found to be misregulated in several types of cancer tissues (Grimm et al., 2019).

We report here a male child with DD, severe ID, microcephaly, recurrent infections, thick eyebrows, long eyelashes, thick scalp hair and hypospadias. Exome sequencing uncovered a novel likely pathogenic de novo variant in $S O X 11$, a gene in which mutations were recently associated with SSRIDDs, two cases of which were classified by authors as CSS (Tsurusaki et al., 2014).

The residue affected in this SOX11 variant is located within the high mobility group (HMG) domain, a motif shared by SOX proteins (Bowles et al., 2000; Schepers et al., 2002). This DNA-binding domain is essential for SOX11's role as a transcriptional regulator, and thus affects various developmental processes (Dodonova et al., 2020). This domain, including the residue affected in the patient reported here, has been shown to be conserved across several species (Bowles et al., 2000; Schepers et al., 2002; Figure 3). Five out of the eight SOX11 reported variants (including this study) fall within this HMG domain (Figure 3). The four variants which localize in this domain have been found to affect downstream transcriptional activity in vitro (Hempel et al., 
2016, Tsurusaki et al., 2014). The variant reported here is similarly expected to affect expression of downstream SOX11 targets, especially considering that the HMG domain is predicted to be lost due to this mutation by the in silico tools we used.

Interestingly, all reported SOX11 related cases, including the current study, are de novo mutations. Moreover, the mutations reported in genes of the BAF complex and related proteins that have been associated with SSRIDDs are also mainly de novo variants (Bögershausen and Wollnik 2018). This is consistent with the finding that de novo mutations play a major role in neurodevelopmental, early-onset and rare disorders (Veltman and Brunner, 2012; Acuna-Hidalgo et al., 2016).

SSRIDDs are a genetically and phenotypically heterogeneous class of disorders caused by pathogenic variants in the BAF complex genes including SMARCA2, SMARCB1, SMARCA4, SMARCE1, ARIDIA, ARIDIB, DPF2, as well as PHF6 and SOX11 (Hoyer et al., 2012; Santen et al., 2012; Tsurusaki et al. 2012, 2014a, 2014b; Van Houdt et al, 2012; Wieczorek et al., 2013; Vasileiou et al., 2018). The BAF complex is an ATP-dependent chromatin remodeling complex required for regulating gene expression. While this complex has biologically diverse functions, it is particularly critical in embryonic neural development as it promotes the proliferation of neural progenitor cells, neurogenic cell division, migration of immature neurons and dendritic morphogenesis (Yoo et al., 2009; Sokpor et al., 2017). SOX11 expression is regulated by the BAF complex pathway, specifically through the transcription factor PAX6 (Wurm et al., 2008, Ninkovic et al., 2013) which could explain the overlapping symptoms of SOX11-related disorders with those of other SSRIDDs.

CSS is a rare autosomal dominant, multiple malformation SSRIDD resulting in numerous features including ID, DD, facial dysmorphia, sparse scalp hair, hypertrichosis, frequent infections 
and feeding difficulties (Vergano and Deardorff, 2014; Santen et al., 2013). However, its defining characteristic appears to be hypoplasia of the fifth digit nails, followed by hypoplasia of the fifth digit phalanges, earning it the moniker of 'fifth digit syndrome' (Mannino et al., 2018). Tsurusaki et al. (2014) studied 92 CSS patients, and identified two cases amongst them with SOX11 mutations. Three other individuals with SOX11 mutations were identified by Hempel et al. (2016) and were reported as having a 'Neurodevelopmental disorder with CSS features' rather than being diagnosed with CSS. A similar diagnosis was reported by Okamoto et al. (2018) for an individual with a SOX11 variant, while Khan et al. (2017) described a child with a SOX11 mutation as having a 'phenotype resembling mild CSS'. Interestingly, a recent study reported a SOX4 variant in a patient exhibiting overlapping features as patients with SOX11 variants (Zawerton et al., 2019). This is consistent with the fact that SOX4 and SOX11 belong to the same subgroup of SOX proteins and share a similar expression pattern (Schepers et al., 2002). Whether or not SOX4 patients should be classified as SSRIDDs will become more clear as more reports of SOX4 variants emerge.

The clinical features of these seven subjects (shown in Table 1) vary widely, but fall within the spectrum of SSRIDDs phenotypes. Based on the clinical features described here, in particular the absence of fifth digit hypoplasia and of classic CSS facial features (such as coarse facies, sparse scalp hair and hypertrichosis), and in accordance with other reported cases of SOX11 mutations (Hempel et al., 2016; Khan et al., 2017; Okamoto et al., 2018), this patient does not fit the CSS clinical profile. Instead, as proposed by Bögershausen and Wollnik (2018), individuals with SOX11 variants, like the patient reported here, should be classified as having a distinct SOX11related SSRIDD. 


\section{References}

Acuna-Hidalgo, R., Veltman, J. A., \& Hoischen, A. (2016). New insights into the generation and role of de novo mutations in health and disease. Genome biology, 17(1), 241. https://doi.org/10.1186/s13059-016-1110-1

Adzhubei, I. A., Schmidt, S., Peshkin, L., Ramensky, V. E., Gerasimova, A., Bork, P., Kondrashov, A. S., \& Sunyaev, S. R. (2010). A method and server for predicting damaging missense mutations. Nature methods, 7(4), 248-249. https://doi.org/10.1038/nmeth0410-248

Bergsland, M., Ramsköld, D., Zaouter, C., Klum, S., Sandberg, R., \& Muhr, J. (2011). Sequentially acting Sox transcription factors in neural lineage development. Genes \& development, 25(23), 2453-2464. https://doi.org/10.1101/gad.176008.111

Bögershausen, N., \& Wollnik, B. (2018). Mutational Landscapes and Phenotypic Spectrum of SWI/SNF-Related Intellectual Disability Disorders. Frontiers in molecular neuroscience, 11, 252. https://doi.org/10.3389/fnmol.2018.00252

Bowles, J., Schepers, G., \& Koopman, P. (2000). Phylogeny of the SOX family of developmental transcription factors based on sequence and structural indicators. Developmental biology, 227(2), 239-255. https://doi.org/10.1006/dbio.2000.9883 
Choi, Y., Sims, G. E., Murphy, S., Miller, J. R., \& Chan, A. P. (2012). Predicting the functional effect of amino acid substitutions and indels. PloS one, 7(10), e46688. https://doi.org/10.1371/journal.pone.0046688

Dodonova, S. O., Zhu, F., Dienemann, C., Taipale, J., \& Cramer, P. (2020). Nucleosome-bound SOX2 and SOX11 structures elucidate pioneer factor function. Nature, 580(7805), 669-672. https://doi.org/10.1038/s41586-020-2195-y

Grimm, D., Bauer, J., Wise, P., Krüger, M., Simonsen, U., Wehland, M., Infanger, M., \& Corydon, T. J. (2019). The role of SOX family members in solid tumours and metastasis. Seminars in cancer biology, S1044-579X(18)30141-X. Advance online publication. https://doi.org/10.1016/j.semcancer.2019.03.004

Hempel, A., Pagnamenta, A. T., Blyth, M., Mansour, S., McConnell, V., Kou, I., Ikegawa, S., Tsurusaki, Y., Matsumoto, N., Lo-Castro, A., Plessis, G., Albrecht, B., Battaglia, A., Taylor, J. C., Howard, M. F., Keays, D., Sohal, A. S., DDD Collaboration, Kühl, S. J., Kini, U., ... McNeill, A. (2016). Deletions and de novo mutations of SOX11 are associated with a neurodevelopmental disorder with features of Coffin-Siris syndrome. Journal of medical genetics, 53(3), 152-162. https://doi.org/10.1136/jmedgenet-2015-103393

Hoyer, J., Ekici, A. B., Endele, S., Popp, B., Zweier, C., Wiesener, A., Wohlleber, E., Dufke, A., Rossier, E., Petsch, C., Zweier, M., Göhring, I., Zink, A. M., Rappold, G., Schröck, E., Wieczorek, D., Riess, O., Engels, H., Rauch, A., \& Reis, A. (2012). Haploinsufficiency of ARID1B, a member 
of the SWI/SNF-a chromatin-remodeling complex, is a frequent cause of intellectual disability. American journal of human genetics, 90(3), 565-572. https://doi.org/10.1016/j.ajhg.2012.02.007

Jankowski, M. P., Cornuet, P. K., McIlwrath, S., Koerber, H. R., \& Albers, K. M. (2006). SRYbox containing gene 11 (Sox11) transcription factor is required for neuron survival and neurite growth. Neuroscience, 143(2), 501-514. https://doi.org/10.1016/j.neuroscience.2006.09.010

Jay, J. J., \& Brouwer, C. (2016). Lollipops in the Clinic: Information Dense Mutation Plots for Precision Medicine. PloS one, 11(8), e0160519. https://doi.org/10.1371/journal.pone.0160519

Kavyanifar, A., Turan, S., \& Lie, D. C. (2018). SoxC transcription factors: multifunctional regulators of neurodevelopment. Cell and tissue research, 371(1), 91-103. https://doi.org/10.1007/s00441-017-2708-7

Khan, U., Study, D., Baker, E., \& Clayton-Smith, J. (2018). Observation of Cleft Palate in an Individual with SOX11 Mutation: Indication of a Role for SOX11 in Human Palatogenesis. The Cleft palate-craniofacial journal : official publication of the American Cleft Palate-Craniofacial Association, 55(3), 456-461. https://doi.org/10.1177/1055665617739312

Kumar, P., Henikoff, S., \& Ng, P. C. (2009). Predicting the effects of coding non-synonymous variants on protein function using the SIFT algorithm. Nature protocols, 4(7), 1073-1081. https://doi.org/10.1038/nprot.2009.86 
Mannino, E. A., Miyawaki, H., Santen, G., \& Schrier Vergano, S. A. (2018). First data from a parent-reported registry of 81 individuals with Coffin-Siris syndrome: Natural history and management recommendations. American journal of medical genetics. Part A, 176(11), 22502258. https://doi.org/10.1002/ajmg.a.40471

Mu, L., Berti, L., Masserdotti, G., Covic, M., Michaelidis, T. M., Doberauer, K., Merz, K., Rehfeld, F., Haslinger, A., Wegner, M., Sock, E., Lefebvre, V., Couillard-Despres, S., Aigner, L., Berninger, B., \& Lie, D. C. (2012). SoxC transcription factors are required for neuronal differentiation in adult hippocampal neurogenesis. The Journal of neuroscience : the official journal of the Society for Neuroscience, 32(9), 3067-3080. https://doi.org/10.1523/JNEUROSCI.4679-11.2012

Ninkovic, J., Steiner-Mezzadri, A., Jawerka, M., Akinci, U., Masserdotti, G., Petricca, S., Fischer, J., von Holst, A., Beckers, J., Lie, C. D., Petrik, D., Miller, E., Tang, J., Wu, J., Lefebvre, V., Demmers, J., Eisch, A., Metzger, D., Crabtree, G., Irmler, M., .. Götz, M. (2013). The BAF complex interacts with Pax6 in adult neural progenitors to establish a neurogenic cross-regulatory transcriptional network. Cell stem cell, $\quad$ 13(4), $403-418$. https://doi.org/10.1016/j.stem.2013.07.002

Okamoto, N., Ehara, E., Tsurusaki, Y., Miyake, N., \& Matsumoto, N. (2018). Coffin-Siris syndrome and cardiac anomaly with a novel SOX11 mutation. Congenital anomalies, 58(3), 105107. https://doi.org/10.1111/cga.12242 
Potzner, M. R., Tsarovina, K., Binder, E., Penzo-Méndez, A., Lefebvre, V., Rohrer, H., Wegner, M., \& Sock, E. (2010). Sequential requirement of Sox4 and Sox11 during development of the sympathetic nervous system. Development (Cambridge, England), 137(5), 775-784. https://doi.org/10.1242/dev.042101

Rentzsch, P., Witten, D., Cooper, G. M., Shendure, J., \& Kircher, M. (2019). CADD: predicting the deleteriousness of variants throughout the human genome. Nucleic acids research, 47(D1), D886-D894. https://doi.org/10.1093/nar/gky1016

Salerno, K. M., Jing, X., Diges, C. M., Cornuet, P. K., Glorioso, J. C., \& Albers, K. M. (2012). Sox11 modulates brain-derived neurotrophic factor expression in an exon promoter-specific manner. Journal of neuroscience research, 90(5), 1011-1019. https://doi.org/10.1002/jnr.23010

Santen, G. W., Clayton-Smith, J., \& ARID1B-CSS consortium (2014). The ARID1B phenotype: what we have learned so far. American journal of medical genetics. Part C, Seminars in medical genetics, 166C(3), 276-289. https://doi.org/10.1002/ajmg.c.31414

Sayers, E. W., Barrett, T., Benson, D. A., Bolton, E., Bryant, S. H., Canese, K., Chetvernin, V., Church, D. M., DiCuccio, M., Federhen, S., Feolo, M., Fingerman, I. M., Geer, L. Y., Helmberg, W., Kapustin, Y., Landsman, D., Lipman, D. J., Lu, Z., Madden, T. L., Madej, T., .. Ye, J. (2011). Database resources of the National Center for Biotechnology Information. Nucleic acids research, 39 (Database issue), D38-D51. https://doi.org/10.1093/nar/gkq1172 
Schepers, G. E., Teasdale, R. D., \& Koopman, P. (2002). Twenty pairs of sox: extent, homology, and nomenclature of the mouse and human sox transcription factor gene families. Developmental cell, 3(2), 167-170. https://doi.org/10.1016/s1534-5807(02)00223-X

Schwarz, J. M., Cooper, D. N., Schuelke, M., \& Seelow, D. (2014). MutationTaster2: mutation prediction for the deep-sequencing age. Nature methods, 11(4), 361-362. https://doi.org/10.1038/nmeth.2890

Sha, L., Kitchen, R., Porteous, D., Blackwood, D., Muir, W., \& Pickard, B. (2012). SOX11 target genes: implications for neurogenesis and neuropsychiatric illness. Acta neuropsychiatrica, 24(1), 16-25. https://doi.org/10.1111/j.1601-5215.2011.00583.x

Shim, S., Kwan, K. Y., Li, M., Lefebvre, V., \& Sestan, N. (2012). Cis-regulatory control of corticospinal system development and evolution. Nature, 486(7401), 74-79. https://doi.org/10.1038/nature11094

Sock, E., Rettig, S. D., Enderich, J., Bösl, M. R., Tamm, E. R., \& Wegner, M. (2004). Gene targeting reveals a widespread role for the high-mobility-group transcription factor Sox11 in tissue remodeling. Molecular and cellular biology, 24(15), 6635-6644. https://doi.org/10.1128/MCB.24.15.6635-6644.2004 
Sokpor, G., Xie, Y., Rosenbusch, J., \& Tuoc, T. (2017). Chromatin Remodeling BAF (SWI/SNF) Complexes in Neural Development and Disorders. Frontiers in molecular neuroscience, 10, 243. https://doi.org/10.3389/fnmol.2017.00243

Tsurusaki, Y., Okamoto, N., Ohashi, H., Kosho, T., Imai, Y., Hibi-Ko, Y., Kaname, T., Naritomi, K., Kawame, H., Wakui, K., Fukushima, Y., Homma, T., Kato, M., Hiraki, Y., Yamagata, T., Yano, S., Mizuno, S., Sakazume, S., Ishii, T., Nagai, T., ... Matsumoto, N. (2012). Mutations affecting components of the SWI/SNF complex cause Coffin-Siris syndrome. Nature genetics, 44(4), 376-378. https://doi.org/10.1038/ng.2219

Tsurusaki, Y., Koshimizu, E., Ohashi, H., Phadke, S., Kou, I., Shiina, M., Suzuki, T., Okamoto, N., Imamura, S., Yamashita, M., Watanabe, S., Yoshiura, K., Kodera, H., Miyatake, S., Nakashima, M., Saitsu, H., Ogata, K., Ikegawa, S., Miyake, N., \& Matsumoto, N. (2014a). De novo SOX11 mutations cause Coffin-Siris syndrome. Nature communications, 5, 4011. https://doi.org/10.1038/ncomms5011

Tsurusaki, Y., Okamoto, N., Ohashi, H., Mizuno, S., Matsumoto, N., Makita, Y., Fukuda, M., Isidor, B., Perrier, J., Aggarwal, S., Dalal, A. B., Al-Kindy, A., Liebelt, J., Mowat, D., Nakashima, M., Saitsu, H., Miyake, N., \& Matsumoto, N. (2014b). Coffin-Siris syndrome is a SWI/SNF complex disorder. Clinical genetics, 85(6), 548-554. https://doi.org/10.1111/cge.12225

Van Houdt, J. K., Nowakowska, B. A., Sousa, S. B., van Schaik, B. D., Seuntjens, E., Avonce, N., Sifrim, A., Abdul-Rahman, O. A., van den Boogaard, M. J., Bottani, A., Castori, M., Cormier- 
Daire, V., Deardorff, M. A., Filges, I., Fryer, A., Fryns, J. P., Gana, S., Garavelli, L., GillessenKaesbach, G., Hall, B. D., ... Vermeesch, J. R. (2012). Heterozygous missense mutations in SMARCA2 cause Nicolaides-Baraitser syndrome. Nature genetics, 44(4), 445-S1. https://doi.org/10.1038/ng.1105

Vasileiou, G., Vergarajauregui, S., Endele, S., Popp, B., Büttner, C., Ekici, A. B., Gerard, M., Bramswig, N. C., Albrecht, B., Clayton-Smith, J., Morton, J., Tomkins, S., Low, K., Weber, A., Wenzel, M., Altmüller, J., Li, Y., Wollnik, B., Hoganson, G., Plona, M. R., ... Reis, A. (2018). Mutations in the BAF-Complex Subunit DPF2 Are Associated with Coffin-Siris Syndrome. American journal of human genetics, 102(3), 468-479. https://doi.org/10.1016/j.ajhg.2018.01.014

Veltman, J. A., \& Brunner, H. G. (2012). De novo mutations in human genetic disease. Nature reviews. Genetics, 13(8), 565-575. https://doi.org/10.1038/nrg3241

Vergano, S. S., \& Deardorff, M. A. (2014). Clinical features, diagnostic criteria, and management of Coffin-Siris syndrome. American journal of medical genetics. Part C, Seminars in medical genetics, 166C(3), 252-256. https://doi.org/10.1002/ajmg.c.31411

Wang, Y., Lin, L., Lai, H., Parada, L. F., \& Lei, L. (2013). Transcription factor Sox11 is essential for both embryonic and adult neurogenesis. Developmental dynamics : an official publication of the American Association of Anatomists, 242(6), 638-653. https://doi.org/10.1002/dvdy.23962 
Wegner M. (2010). All purpose Sox: The many roles of Sox proteins in gene expression. The international journal of biochemistry \& cell biology, 42(3), 381-390. https://doi.org/10.1016/j.biocel.2009.07.006

Wieczorek, D., Bögershausen, N., Beleggia, F., Steiner-Haldenstätt, S., Pohl, E., Li, Y., Milz, E., Martin, M., Thiele, H., Altmüller, J., Alanay, Y., Kayserili, H., Klein-Hitpass, L., Böhringer, S., Wollstein, A., Albrecht, B., Boduroglu, K., Caliebe, A., Chrzanowska, K., Cogulu, O., ... Wollnik, B. (2013). A comprehensive molecular study on Coffin-Siris and Nicolaides-Baraitser syndromes identifies a broad molecular and clinical spectrum converging on altered chromatin remodeling. Human molecular genetics, 22(25), 51215135. https://doi.org/10.1093/hmg/ddt366

Wurm, A., Sock, E., Fuchshofer, R., Wegner, M., \& Tamm, E. R. (2008). Anterior segment dysgenesis in the eyes of mice deficient for the high-mobility-group transcription factor Sox11. Experimental eye research, 86(6), 895-907. https://doi.org/10.1016/j.exer.2008.03.004

Yoo, A. S., Staahl, B. T., Chen, L., \& Crabtree, G. R. (2009). MicroRNA-mediated switching of chromatin-remodelling complexes in neural development. Nature, 460(7255), 642-646. https://doi.org/10.1038/nature08139

Zawerton, A., Yao, B., Yeager, J. P., Pippucci, T., Haseeb, A., Smith, J. D., Wischmann, L., Kühl, S. J., Dean, J., Pilz, D. T., Holder, S. E., Deciphering Developmental Disorders Study, University 
of Washington Center for Mendelian Genomics, McNeill, A., Graziano, C., \& Lefebvre, V. (2019).

De Novo SOX4 Variants Cause a Neurodevelopmental Disease Associated with Mild

Dysmorphism. American journal of human genetics, 104(2), 246-259. https://doi.org/10.1016/j.ajhg.2018.12.014 


\section{Legends}

Table 1: Clinical features of reported SOX11 patients

Figure 1: Images of reported patient highlighting facial features (a), hand (b) and foot $(c)$.

Figure 2: Sanger sequencing electropherogram showing the SOX11 variant c.146T $>\mathrm{A}$ in the patient.

Figure 3: Previously reported variants depicted on a linear representation of SOX11, with the variant reported here, p.Ile49Asn, shown in blue. Alignment of residues around the affected amino acid (highlighted in yellow), showing conservation across several species. 



C

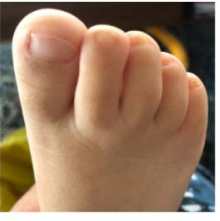



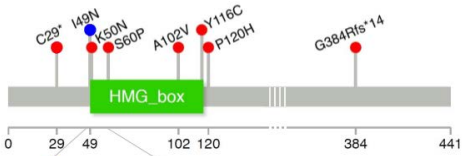

HIKRPMNAFMVWS H.sapiens

HNKRPMNAFMVWS Reported variant

HIKRPMNAFMVWS P.troglodytes

HIKRPMNAFMVWS M.mulatta

HIKRPMNAFMVWS M.musculus

HIKRPMNAFMVWS R.norvegicus

HIKRPMNAFMVWS G.gallus

HIKRPMNAFMVWS D.rerio

HIKRPMNA FMVWS X.tropicalis

HIKRPMNAFMVWS D.melanogaster

HIKRPMNAFMVWS C.elegans 
Table 1: Clinical features of reported SOX11 patients

\begin{tabular}{|c|c|c|c|c|c|c|c|c|}
\hline & \multicolumn{2}{|c|}{ Tsurusaki et al. (2014) } & \multicolumn{3}{|c|}{ Hempel et al. (2016) } & \multirow{2}{*}{$\begin{array}{c}\text { Khan et al. } \\
(2017)\end{array}$} & \multirow{2}{*}{$\begin{array}{l}\text { Okamoto et al. } \\
\qquad(2018)\end{array}$} & \multirow[t]{2}{*}{ Current study } \\
\hline & Subject 1 & Subject 2 & Subject 8 & Subject 9 & Subject 10 & & & \\
\hline \multicolumn{9}{|l|}{ Subject details } \\
\hline Gender & Female & Female & Female & Male & Male & Male & Male & Male \\
\hline Origin & Japanese & Indian & Caucasian* & Caucasian* & Caucasian* & Caucasian* & Japanese & Lebanese \\
\hline SOX11 Mutation & $\begin{array}{c}\text { c. } 347 \mathrm{~A}>\mathrm{G} \\
\text { (p.Tyr116Cys) }\end{array}$ & $\begin{array}{c}\text { c. } 178 \mathrm{~T}>\mathrm{C} \\
\text { (p.Ser60Pro) }\end{array}$ & $\begin{array}{c}\text { c. } 359 \mathrm{C}>\mathrm{A} \\
\text { (p. Pro120His) }\end{array}$ & $\begin{array}{c}\text { c.150G }>C \\
(p . \\
\text { Lys50Asn) }\end{array}$ & $\begin{array}{c}\text { c. } 87 \mathrm{C}>\mathrm{A} \\
\left.\text { (p. Cys } 29^{*}\right)\end{array}$ & $\begin{array}{l}\text { c.1148dupG } \\
\text { (p.Gly384Arg } \\
\text { fsTer14) }\end{array}$ & $\begin{array}{c}\text { c. } 305 \mathrm{C}>\mathrm{T} \\
\text { (p.Ala102Val) }\end{array}$ & $\begin{array}{c}\text { c.146T>A } \\
\text { (p.Ile49Asn) }\end{array}$ \\
\hline \multicolumn{9}{|l|}{ CNS Features } \\
\hline $\begin{array}{l}\text { Developmental } \\
\text { Delay }\end{array}$ & + & + & + & + & + & + & + & + \\
\hline
\end{tabular}




\begin{tabular}{|c|c|c|c|c|c|c|c|c|}
\hline $\begin{array}{l}\text { Intellectual } \\
\text { Disability }\end{array}$ & $\stackrel{+}{+}$ & $\stackrel{+}{+}$ & $\begin{array}{c}+ \\
\text { (severe) }\end{array}$ & $\begin{array}{c}+ \\
\text { (severe?) }\end{array}$ & $\begin{array}{c}+ \\
\text { (mild?) }\end{array}$ & $\begin{array}{c}+ \\
\text { (mild) }\end{array}$ & $\begin{array}{c}+ \\
\text { (mild) }\end{array}$ & $\begin{array}{c}+ \\
\text { (severe) }\end{array}$ \\
\hline Hypotonia & + & - & $N / R$ & $N / R$ & $\mathrm{~N} / \mathrm{R}$ & + & - & + \\
\hline Microcephaly & + & + & + & + & - & - & - & + \\
\hline \multicolumn{9}{|l|}{ Facial Features } \\
\hline Coarse Facies & - & - & + & - & + & - & + & - \\
\hline Thick Eyebrows & - & - & - & - & - & + & - & + \\
\hline $\begin{array}{l}\text { Long/Prominent } \\
\text { Eyelashes }\end{array}$ & + & - & - & - & - & - & - & + \\
\hline $\begin{array}{l}\text { Hypoplasia of } 5 \text { th } \\
\text { fingernail/toenail }\end{array}$ & + & + & + & + & + & + & + & - \\
\hline $\begin{array}{l}\text { Clinodactyly of } \\
5 \text { th finger }\end{array}$ & + & + & + & + & + & + & + & - \\
\hline
\end{tabular}




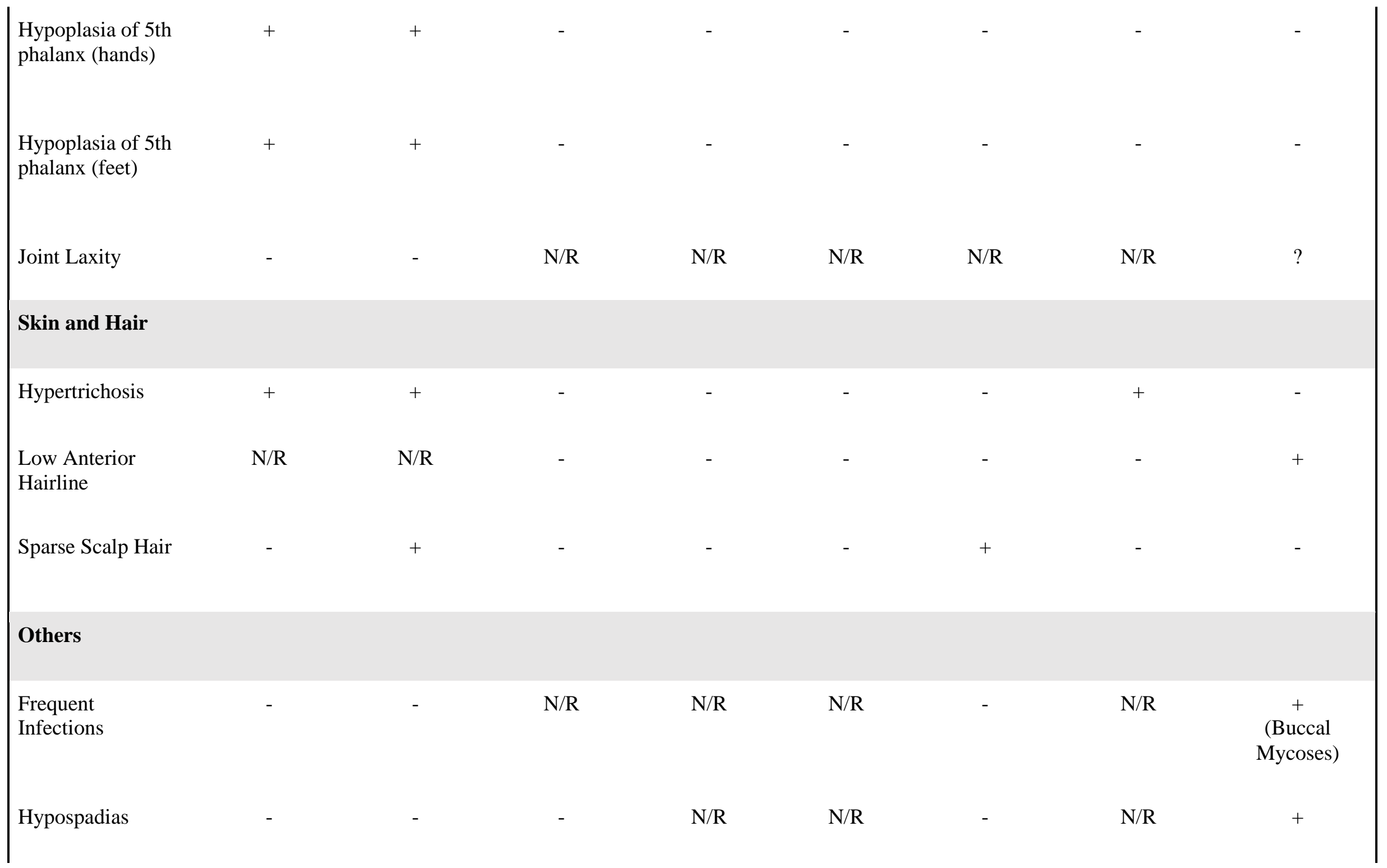


* Ethnicity not reported. Subjects were presumed to be caucasian based on their photos N/R: Not Reported 